\title{
Discretion as Freedom of Action in Administering Governance
}

\author{
Siti Kunarti $^{1 *}$ and Kartono ${ }^{1}$ \\ ${ }^{1}$ Faculty of Law, Jenderal Soedirman University, Purwokerto, Central Java, Indonesia
}

\begin{abstract}
The concept of discretion in public administration basically brings significant positive energy when viewed in the perspective of virtue for the morality-based governance (law). Government as the holder of discretion power holds an important power, yet not for itself. In this way, in exercising discretion, government not only may take actions out of the specific prescription in the law, but also may take actions contradicting the law for common good. Such actions are justifiable as long as they are intended for public interest and public good; not for the sake of itself. Such action cannot be blamed within public administration, as long as the purpose is in accordance with the purpose of the state's constitution for common good and prosperity.
\end{abstract}

\section{Introduction and literature Review}

The existence and role of public administration as public service (bestuurzorg) allows its active participation in all aspects of community life. The interest of public administration is meant to improve public good. One of the logical consequences of this state welfare function is the freedom given to public administration to take action based on individual initiatives within certain limits (discretion). The concept of discretion has been the topic of long discretion. This paper deals with the concept in comprehensive manner to argue that discretion power has not yet received the freedom it deserves in its real governance in Indonesia.

In welfare state, the duty of government is not merely executing the law produced by legislative body. In the perspective of welfare state, government is obligated to administer public governance, maintaining social welfare of course within the legal corridor. Government here is referred as an organization that owns governing power, while governance means the process of governing or administering a state. The power holder in this case is the government, who governs and administers public interest. In practice administration is held by administering body of officers with authorization. In its development, the function of government changes from only an institution making and enforcing law, to an institution executing law and administering public service.

The practical characteristic of governance in modern legal state in order to administer public service is the freedom owned by the government, meaning that government is not strictly tied to the rule and regulation in administering public service and governance. The reason is that in administering governance, officers of institutions are face to face with the complexity, dynamicity, and development of social matters. If strictly following the rule and regulation, government will be too rigid. In real practice, government needs freedom of

*Corresponding author : siti_kunarti@yahoo.co.id 
initiatives and wisdom especially over urgent and unexpected matters which law and regulation have not yet prescribed. This freedom is called discretion.

Government and administering bodies are subject to law or the enforcer of rights and duties. As all other legal subjects, government does concrete actions as well as legal actions. Legal actions of government are intended to enforce right and duties.

In the perspective of Public Administration Law study, these legal actions are realized in legal and policy instruments. They are regulation (regeling), decree (besluit), policy guideline (beleidsregel), and decision (beschikking).

Discretion power is a concept that needs to be understood in thorough and critical manner since it is very potential to be misunderstood. The flow of mainstream view was strong enough to result Law No. 30 Year 2014 about Public Administration. The author extremely holds the opposite view from those mainstreams by disagreeing with the Law No. 30 Year 2014.

The author departs from the principle that government's discretion power is a product of legal authorization, not constitutive. Therefore, the author refuses positivistic or legalistic view of discretion power. This, the author believes, is the fundamental mistake of the mainstream, regarding with Law No. 30 Year 2014.

Discretion has significant positive result when viewed as a virtue that is based on morality. A government with discretion holds this significant power, but it is not for the sake of the government, nor for the power itself. In that way, government may take actions that are not yet prescribed within the law or are even contradictive to the law and regulation. However, this is justifiable as long as they are meant for public good, not for self interest.

Such action of discretion is correct and unblameable as long as it is preconditioned with good intention and wisdom under the framework of public good and interest. This claim is strongly based on constitutionalist teaching. For example, Locke says "Salus Populi Suprema Lex, is certainly so just and fundamental a Rule, that he, who sincerely follows it, cannot dangerously err.' [1]. For the sake of 'Sallus Populi',government's action of discretion that is not prescribed in or is contradictive to the law is justifiable. This is a concept of discretion as a product of legal authorization as opposed to the Law No. 30 Year 2014 as well as positivistic and legalistic mainstream.

\section{Objective of the study}

The question of the research is: How is the concept of discretion exercised in governance?

\section{Methodology}

To describe discretion as freedom of action, this research employs Normative Judicial and Legal approach, which constitutes the study of primary and secondary legal materials.

\section{Discussion}

\subsection{The Concept of Power and Discretion Power}

Theoretically, the concept of power is divided into two categories. First, power based on "general rule of law" and; second, "personal discretion to do justice." This concept is described by Antonin Scalia departing from the conceptual framework of Aristotle's Politics. According to Aristoteles: 
"Rightly constituted laws should be the final sovereign; and personal rule, whether it be exercised by a single person or a body of persons, should be sovereign only in those matters on which law is unable, owing to the difficulty of framing general rules for all contingencies, to make an exact pronouncement." [2].

Abstractly, discretion can be defined as free power; power based on personal and subjective consideration of the power holder to take an action. The holder of discretion power has freedom to take an action facing a casuistic situation [3]. The concept of discretion power is highly contrasted with the power based on "genera rule of law."

Therefore, it is an exception to the power based on "general rule of law". In this way, discretion is a free power that is exercised without accordance with the pre-existing law and regulation. The holder of discretion power does not necessarily base himself strictly on law and constitution (Purbapranoto in page 44). As the result, discretion power can only apply in casuistic or contextual way.

Legal limitation of discretion needs to apply correctly. Scalia declares his position in the case of limitation of discretion power as public desire of legal nation within democratic governmental system. It means that law and regulation that clearly and completely prescribes itself is the ideal expectation of everybody. But the reality is different (Scalia, in page 11). In this case, discretion is important.

The incentive of the necessity of discretion is the active modern governance, which is called bestuurzorg, which functions not only to govern but also to take care (ordende enverzorgende) [4]. Based from such conception, government is expected not to be passive or waiting, although law and regulation do not prescribe an action (lacunae), or at least are obscure or vague in their prescription concerning public good (bonum commune).

The scope of discretion extends to all aspect of governance (bestuursanderlingen), minus legislative and judiciary government. The fields include at least: delegated legislation, governmental regulation; factual actions; political actions and law enforcement; governmental sanctions, etc. [5]. The government here refers to the central and regional government who govern the entire administration and governance [6]. Those central and regional governments can be a functional officer as well as governmental institution (Purbopranoto in page 42-43).

\subsection{Definition of Discretion}

Etymologically, the word discretion stemmed from discerne (Latin). This word has English equivalent discernment and judgment [7]. This definition is similar to the lexical meaning in Black's Law Dictionary that defines discretion as: "Wise conduct and management: cautious discerment, especially as to matter of propriety and self-control; prudence; circumspection; warines." [8]. Such definition indicates a serious misunderstanding in explaining discretion in theoretical-conceptual level, especially in dealing with antinomy context in which legality principle is negatively framed as demand of legally based actions so that such action is correct according to the Law. Such is a wrong understanding of the concept of discretion and correct perspective is needed to give fair and positive meaning to the concept of discretion.

The correct perspective of discretion is "An exercise of discretion is subject to reversal only if the discretion is abused." (Fletcher in page 271). Based on this definition, discretion is a judicial legal concept about legitimate government's power in which government officer or institution has right of legal protection. As the consequence, action of discretion has negative value only if there is abuse of that discretion. With this basis, analysis of discretion is focused on the opposite of normal action that demands officer or institution to act according to the rule within legal framework (rule of law).

According to Maurice Rosenberg, in that situation, discretion means: "a decision maker has a wide range of choice as to what he decides, free from the constraints which 
characteristically attach whenever legal rules enter the decision process" [9]. That opinion is supported by Kenneth Culp Davis that explains precondition of discretion power as follows: "An administrator has discretion whenever the effective limits on his power leave him free to make a choice among possible courses of action or inaction." Davis continues to explain the scope of discretion: "Discretion is not limited to what is authorized but includes all that is within 'the effective limits' on the officer's power." [10].

Viewing those opinion, discretion is essentially a tendency to act within the corridor of general rule of the law and regulation (rule-based approach). This exception characterizes a strong relationship between discretion and freedom with a large functional scope in accordance with the scope of authority owned by a government officer or institution. There is an opinion saying that government officers or institutions inherently have freedom of action without legal authorization. This view comes from the assumption that government can do anything as long as it does not breach the law or individual rights. That means, the law or court verdict may limit such freedom as long as contradictory actions are not taken, government has freedom. This view is conceptualized and "the third source of authority for government action" developed by B.V Harris from New Zealand [11].

The definition of discretion seems more concrete in Charles H. Koch Jr. who explains that the spirit of discretion is to protect officers who exercise it, in the form of room of error when taking discretion actions: "“"all types of discretion are characterized by some sense that the agency needs a degree of freedom to make mistakes." [12]. The argument is supported by J.H Grey, saying that "Discretion may best be defined as the power to make a decision that cannot be determined to be right or wrong in any objective way." [13].

Along with the explanation earlier, Maria O'Sulivan also emphasizes the conceptual meaning of discretion as the opposite of subsumptive actions according to the law [14]. These views are generally in line with those that are accepted in Public Administration study in Indonesia. Departing from the understanding developed by Netherland Public Administration study, the conceptual meaning of discretion is as follows:

"The administrative authority can weigh the different interests and give its own administrative judgment. In this case, there is a lack of detailed regulations in the background law on which the decision rests: it is left to the insight of the administrative authority to use the power in a sensible manner."

While the opposite concept, bind power or authority is defined that "the administration is compelled to act in a prescribed manner."[15]From this explanation, there is asimilarity of definition of the concept of discretion that leads to generalization of the concept.

The discretion described by Locke reveals the most authentic meaning, termed prerogative. The thinking framework that motivates Locke's thought about prerogative is the concept of limited government. Generally, Locke tought the doctrine that the power of government in the framework of limited government by saying that "the powers of government tought to be exercised by established and promulgated laws." Then, as a particular principle of exception, Locke explains prerogative concept, which says " "to act according to discretion, for the public good, without the prescription of the Law, and sometimes even against it."[16]

Locke's concept of discretion exactly describe the governance activity that anticipate the impossibility of expectation that "the powers of government ought to be exercised by established and promulgated laws"; but sometimes, as an exception, government has "to act according to discretion, for the public good, without the prescription of the Law, and sometimes even against it." The underlined keyword as the strong meaning of discretion is not only the absence of authorization, but also the possibility to contradict the law.

Discretion, therefore, does not violate the Locke's concept of limited government. It is necessary as a way of governance when the ideal expectation "the powers of government 
ought tobe exercised by established and promulgated laws" is no longer possible in real governance.[17] Locke's concept of discretion is still relevant and accountable. This view is very applicable not only when the quality of legislation is not functional and not in accordance with the demand of governance, but also when such legislation brings moral failure.

Dealing with moral failing law, it applies that such law is not binding so that citizens is obligated not to follow the law. This view is manifested in Radbuch's statements of substantive validity issue of the law. First, "Where there is not even an attempt at justice, where equality, the core of justice, is deliberately betrayed in the issuance of positive law, then the statute is not merely 'flawed law', it lacks completely the very nature of law." Second, "There can be laws that are so unjust and so socially harmful that validity, indeed legal character itself, must be denied them."[18]

Discretion power, therefore, similar to a decision or action of individual when effective limitation of power free him to make option based on taking or not taking action for public good without prescription, even by contradicting the prescribed law.

\subsection{Discretion: Free Power}

The issue of government's power of discretion is not about the process of how this power is acquired, but rather about the technique employed by the government in exercising its a priori power, especially in taking necessary actions. In this way, the issue of discretion is in fact the result of a situation in which the government is expected to exercise power. Furthermore, it is directly related to its implications. Does the government have to take administrative action or not; will it lead to positive or negative implication when action is taken or not taken.

In such condition, when dealing with power exercise, government must strictly follow the rules and guidelines of law and constitution to guide how the government should take action; or vice versa, government may not follow the rules and guidelines of law and constitution in taking actions, even when necessary it takes actions that contradict the law and constitution. The former condition is called "bind power", and the latter is called "free power" or discretion.

One important point needs to be emphasized here, so that conception misunderstanding may be avoided. Before the government takes actions based on discretion, it must have the basis of its general power. In relation with governmental action, discretion action may take place only when the power of the government has already existed in the first place. Just like its characteristic, discretion power is not necessarily regulated within the constitution in inherent way. The existing or non-existing discretion power depends entirely on the capability of law-maker in regulating the actions of the government regarding with specific and unpredicted matters.

When the government's way of taking actions can be comprehensively put into law, anticipating all kinds of situations, by the law makers, then as the implication discretion power of the government does not exist. Such condition is a utopia. The expectation that such law can give clarity and basis for the actions is false. Therefore, concerning the characteristic of interrelation between government and law, regulation is nothing but an effort to maximally minimize the exercise of discretion power, never to nullify it. In this way discretion power of the government is inherent and it is not necessary to be authorized by the law.

As argued by Antonin Scalia, referring to Aristotle, in a normal situation general rule of law applies, that the government must exercise its power according to the prescribed law and constitution. If a case is not prescribed in the law, then the government should act based on personal discretion to do justice. In the relation between those two situations, the concept of discretion power becomes a very interesting legal concept because it deals with legitimation 
that extends to actions that leads away from the law (in more general meaning, from the constitution). This is the most critical issue in the context of government's discretion, when compared to the discretion power exercise preceding the existence of law (in more general term, constitution).

The thesis and arguments for this claim is that although discretion contradicts the law (and the constitution), it is legitimate, and is not an abuse of power. In this case the purpose of such action of discretion as the substantive reason, shall explains whether the action contradicting the law (and constitution) is justifiable or not. If the substantive reason is not justifiable, then the discretion action shall be an abuse of discretion power.

In shorts the interrelation between the government and the constitution is relative. In other words, in exercising governance, the dependence of government on the law is more flexiblesituational. Whereas the interrelation between the government and law is absolute, we, academically, have not yet developed alternative thought that may be related with the obligation to disregard unconstitutional laws in administering public policy. It is very possible that the administration of public policy face unconstitutional laws so it is the option for government to ignore such law and constitution.

In writer's opinion, the relation between government and constitution should be understood in a dynamic context. Though basically each person, as well as government, is obligated to obey the law and constitution as the implication of legality principle, it may not be the case in real governance, especially when dealing with unpredicted situations compared to the scheme of law and regulation. In governance, enforcing law does not completely mean enforcing law in legalistic way. Therefore, it is difficult to say that the government does not contradict the law, or it does not abuse its power, if we use legality principle as the standpoint. In this way, the broad of understanding and conception of law is our main issue so that governmental actions contradicting the law, in terms of discretion power, shall not be judged as an abuse of power.

As seen in practice, it is difficult for the government to avoid legalistic framework in governance. Even the concept of discretion, in the end, will be understood in legal and formal way. Legalistic or legalism means "the ethical attitude that holds moral conduct to be a matter of rule following, and moral relationships to consist of duties and rights determined by rules."

Considering the existing phenomena, it is hardly possible for government to exercise discretion power in exactly similar way to the writer's concept of discretion. But the point is that, it is possible for government to exercise discretion, though contradicts the law, if only the objective condition is fulfilled, that is for "SALUS POPULI." This situation, according to John Locke, authorizes the government "to act according to discretion, for the public good, without the prescription of the Law, and sometimes even against it. Regarding to the objective condition to justify discretion, John Locke says "Salus Populi Suprema Lex, is certainly so just and fundamental a Rule, that he, who sincerely follows it, cannot dangerously err"." Such case is not a power abuse. Such is a necessary action because it is for "Salus Populi".

In this way, inferential definition from the explanation is that the government, in principle, must take an action based on "Salus Populi" as the basis of objectivity and justification, especially in discretion. As long as for "Salus Populi", or public interest, all actions of government is justified, cannot be charged by law, even when the discretion contradicts the legality principle. 


\section{Conclusion}

In its development in Indonesia, the concept of discretion is regulated in the Law No. 30 year 2014 about Public Administration. Article 1 number 9 of the Law No. 30 year 2014 defines discretion as follows:

"Decision and/or action issued and/or executed by government officials to overcome concrete matters faced when administering governance in the case where rule and regulation do not give options, do not prescribe, are incomplete or absurd, and/or in the case of administrative stagnation.

The definition of discretion still strongly holds on legalistic characteristic (positivism), as shown in the phrase "in the case when the law and regulation prescribe options", sodiscretion becomes dependent power. This definition even deviates from the true meaning of discretion itself.

Such misunderstanding of the discretion concept leads to important regulation dealing with the exercise of discretion as prescribed in Chapter 7, article 2, Law No. 30 Year 2014, that obligates government officers to obey the law a quo when exercising discretion. "Government officers have obligations to obey this Law in exercising discretion." The conclusion of a quo is, exactly, that the concept of discretion does not exist, because discretion transforms into power under the law (legality principle).

The regulation of discretion in the Law No. 30 Year 2014 proves that legalistic mindset is still dominant in Indonesia. Such mindset conceptualizes discretion power in a narrow meaning. Indonesian government officers, in central or regional level, are forced to find legal basis for their every discretion action.

The influence of legalistic thought to the concept of discretion power leads to risk in misunderstanding deviate actions. Very often officers are charged with responsibility when committing personal mistakes before regulation, especially when discretion action contradicts the law. Such prescription, especially in the last sentences, is consistent with the prescription of the Law No. 30 Year 2014, but is inconsistent with the true conceptual meaning of discretion power, and in the final analysis, it dangerously leads to endangering government officers who exercise discretion actions that contradicts the law or constitution.

As the result of legalistic thinking framework, discretion power is forced to be framed within the law and constitution (specifically the regulation) as in the case of Law No. 30 Year 2014. As the consequence, Law No. 30 Year 2014 is meaningless to protect government officers in exercising discretion actions because discretion is conceptualized in legalistic frame. Such approach contradicts the true meaning of discretion concept. "Disregard laws" is the right action if it has the purpose "to uphold the Law." This is the essential concept of discretion power, so that appreciation instead of allegation shall apply to government officials when exercising discretion.

\section{References}

1. C. Fatovic, Outside the Law: Emergency and Executive Power, (The John Hopkins University Press, Baltimore, 2009)

2. A. Scalia, lawreview, 56, p. 11, (1989)

3. K. Purbopranoto, Beberapa Catatan Hukum Tata Pemerintahan dan Peradilan Administrasi Negara, (Alumni, Bandung,1975)

4. N.M. Spelt \& J.B.J.M. ten Berge, Pengantar Hukum Perizinan, (Yuridika, Surabaya,1993).

5. P. M. Hadjon, Pengertian-pengertian Dasar tentang Tindak Pemerintahan (Bestuurshandeling), (Djumali, Surabaya,1985) 
6. Pengantar Hukum Administrasi Indonesia (Gadjah Mada University

Press, Yogyakarta, 2002)

7. S. Basah, Perlindungan Hukum Terhadap Sikap Tindak Administrasi Negara, (Alumni, Bandung, 1986),

8. G. P. Fletcher, Law \& Contemp. Probs., 47, p. 270, (1984),

9. H. C. Black, Black's Law Dictionary With Pronunciations, Centennial Edition (1981-1991), p. 323, (1991),

10. G. C. Christie, An Essay on Discretion, Duke L. J., p.747-748, (1986).

11. K. C. Davis, Administrative Law: Cases - Text-Problems, (West Publishing Co., Minnesota, 1977).

12. Matthew Mortimer, Is Positive Authorisation in Law Necessary for Lawful Public Body Action? Dissertation, Bachelor of Laws (honours), University of Otago, p. 8. (2012).

13. C. H. Koch Jr., Geo. Wash. Int'l L. Rev., 54, p. 470. (1986).

14. J.H. Grey, Osgoode Hall L. J., 17, p. 107. (1979).

15. M. Groves \& H.P. Lee, eds., Australian Administrative Law: Fundamentals, Principles and Doctrines (Cambridge University Press, Cambridge, (2007)

16. J.G. Brouwer\& A.E. Schilder, A Survey of Dutch Administrative Law, (Ars Aequi Libri, Nijmegen,1998)

17. V. Ramraj, The Compulsion of Legality, (Cambridge University Press, Cambridge, 2008),

18. Gustav Radbruch, ojls, 26, (2006), (translated by Bonnie Litschewski Paulson \& Stanley L. Paulson) 